\title{
The Impact of Internationalization of Sarbanes-Oxley Act to the U.S. Listed Indonesian Companies
}

\section{| Ahmad Fauzi $^{1}$ | Asri Sitompul ${ }^{2}$ |}

\author{
${ }^{1}$ Universitas Muhammadiyah \\ Sumatera Utara, Medan, \\ Indonesia \\ ${ }^{2}$ Sekolah Tinggi Hukum \\ Galunggung (STHG), \\ Tasikmalaya Jawa Barat, \\ Indonesia \\ 1ahmadfauzi@umsu.ac.id \\ 2asitomp@yahoo.com
}

\begin{abstract}
In every country the existence of capital markets is fundamental in the development of the economy. Capital market, in addition to its function as a means to gather and allocate the public funds. Numerous companies attempted to fix up in order to get into a stock market and do the Initial Public Offering (IPO). But it is not an easy job, various preparations should be carried out and of course it takes some time and effort and considerable cost. In addition to stock market laws, the market is also governed by various regulations issued by the market authorities and stock exchanges as the SRO. In the U.S., the authority is the SEC and in Indonesia the capital market authority is the OJK. Stock exchanges such as the NYSE in the U.S. and Indonesian Stock Exchange (BEI) in Indonesia also issued various rules regulate all companies listed the shares in the stock exchanges. Internationalization means to bring something local to the international level. The Sarbanes-Oxley Act is supposed to applicable only in the U.S, it is not applicable in Indonesia. But the law is brought from the U.S brought to Indonesia to be applied to Indonesian companies that have the stocks listed with the U.S stock market. The application of the Act brought some problems to Indonesian companies that have to comply with all requirements stipulated in the Act.

KEYWORDS

Acts, internationalization; market; SOX; sock
\end{abstract}

\section{INTRODUCTION}

In every country the existence of capital markets is fundamental in the development of the economy. ${ }^{1}$ Capital market, ${ }^{2}$ in addition to its function as a means to gather and allocate the public funds to rebalance their balance sheet after large investment, ${ }^{3}$ also have an important role to the development of the business world that will further support the development of the overall economy of the country. ${ }^{4}$ Securities trading in the capital markets, which is important for the life of the stock market itself, influenced by a variety of factors, among others, the disclosure and availability of corporate information, the existence of a strong authority and regulations. All of these factors will support the

\footnotetext{
${ }^{1}$ Christoph Kaserer and Marc Steffen Rapp (2014). Capital Markets and Economic Growth: Long-Term Trends and Policy Challenges. Research Report, March 2014.

${ }^{2}$ In this paper the terms Capital Market, Securities Market, and Stock Market will be used interchangeably.

${ }^{3}$ Marco Pagano, Fabio Panetta and Luigi Zingales (1998). Why Do Companies Go Public? An empirical Analysis. The Journal of Finance. Vol LIII. No.1. February 1998. p. 29.

${ }^{4}$ Alin Marius Andrieș (2009). The Importance of Capital Market in Economy. CES Working Papers, I, (2), 2009. See also: International Finance Corporation (2017). The Importance of Local Capital Markets for Financing Development. Not 28 January 2017.
} 
establishment of an efficient market, ${ }^{5}$ a market where the prices of shares traded in it reflects information about the state of the company whose shares are traded in the market. ${ }^{6}$

Selling shares in the stock market is one of the ways of funding the company that quite popular worldwide and also in Indonesia is no exception. Numerous companies attempted to fix up in order to get into a stock market and do the Initial Public Offering (IPO). But to get into the market is not an easy job, various preparations should be carried out and of course it takes some time and effort and considerable cost. ${ }^{7}$

In addition to the time and expense and the hassles job in preparation, it also should be considered a variety of laws and regulations that must be obeyed by the company when it has listings on the stock exchange. Preparation indeed take time, since the revamping of the company (housekeeping), improvements of accounting and business process and calculation of the risks faced by the company, as well as the cost should be born since the preparation, due diligence, drafting the prospectus and the drafting of the underwriting agreement is quite large and unavoidable. Once the company (the Issuers) shares listed at the stock market the Issuers encumbered with a variety of reporting and disclosure obligations.

\section{REVIEW OF LITERATURE}

\section{The U.S. Listed Indonesian Companies}

Besides selling its shares on the Indonesian Stock Exchange some Indonesian companies also listed its shares on the United States securities market, including the New York Stock Exchanges (NYSE) ${ }^{8}$ and also there are Indonesian companies' shares traded over-thecounter (OTC) in the U.S. The purpose of listing on the U.S stock exchange may vary, among other is to get fresh money for the company or shareholder, ${ }^{9}$ and to get access to international financial market and to bring the company to international or global level.

By listed on the United States stock exchanges and the Stock Exchange in Indonesia, Indonesian companies should be subject to the laws and regulations concerning stock market and listing requirement and also disclosure requirement imposed by the two countries and issued by all exchanges where their stock publicly listed.

\section{The Stock Market Authorities and Regulations}

The starting point for a discussion of the securities laws of the United States is the Securities Act of 1933 (the 1933 Act) which seeks to prevent the public offering and sale of securities unless adequate information about the securities has been made available to

\footnotetext{
${ }^{5}$ Jonathan Clarke, Tomas Jandik, Gershon Mandelker (2018). The Efficient Markets Hypothesis. http://www.e-m-h.org. Accessed 10 February 2018.

${ }^{6}$ Eugene Fama (1970), "Efficient Capital Markets: A Review of Theory and Empirical Work," Journal of Finance, 25, 383-417. For comparison see: Burton G. Malkiel. The Efficient Market Hypothesis and Its Critics. Princeton University: CEPS Working Paper No. 91 April 2003.

${ }^{7}$ KPMG (2015). A Guide to Going Public. (C) 2015. KPMG LLP, a Canadian limited liability partnership and a member firm of the KPMG network of independent member firms affiliated with KPMG International Cooperative (“KPMG International”), a Swiss entity. See also: EY (2013). EY's guide to going public. Lessons from the leaders. EYGM Limited.

${ }^{8}$ Indonesian companies listed at NYSE including PT. Telekomunikasi Indonesia Tbk (Telkom) and PT. Indonesian Satellite Corporation Tbk. (Indosat).

${ }^{9}$ Belén Gill de Albornoz and Peter F. Pope (2004). The Determinants of the Going Public Decision: Evidence From the U.K. Editor: Instituto Valenciano de Investigaciones Económicas, S.A. Primera Edición Junio 2004. p.5.
} 
the public. ${ }^{10}$ Unlike the 1933 Act, which regulates the initial issuance of securities, the other major U.S. securities statute, the Securities Exchange Act of 1934 (the 1934 Act), is primarily concerned with the trading in securities which are already issued and outstanding, and to this end, regulates issuers, institutions and professionals involved in the securities trading process. ${ }^{11}$ The 1934 Act also established the Securities and Exchange Commission (the Commission) as a regulatory body watching the implementation of both Acts.

In addition to 1933 Act and 1934 Act, the market are also governed by various regulations issued by the market authorities and stock exchanges as the SRO (selfregulatory organization) that is a non-governmental organization that has the power to create and enforce its regulations and standards. In the U.S., the authority is the Securities and Exchange Commission and in Indonesia capital market authority is in the hand of the financial services authority (Otoritas Jasa Keuangan - OJK). Stock exchanges such as the NYSE in the U.S. and Indonesian Stock Exchange (Bursa Efek Indonesia - BEI) in Indonesia also issued various rules that are enforced to all companies listed the shares in the stock exchange.

Authority and regulation is needed to ensure that the market remains 'sustainable' in the sense of not too much 'surprise', which is the down or the rise in stock prices, which in turn result in a rise and down of the index uncontrolled and or unpredictable. ${ }^{12}$ Although rise and down of the price affected the stock and its trading conditions everyday but in some ways extreme rise and down of the price have to be observed and controlled by the capital market authority to keep the market condition and to prevent a 'crash'. ${ }^{13}$

\section{The Sarbanes-Oxley Act}

Although the 1933 Act and 1934 Act were considered as the longest-surviving acts in the field, but the occurrence of the case involving the world's largest accounting firms, the U.S. lawmaker to consider the necessity of the existence of new regulations to prevent the recurrence of violations.

The Sarbanes-Oxley Act (the SOX) came into force in 2002 and introduced major change to the regulation of financial practice and corporate governance. It brings the name of Senator Paul Sarbanes and Representative Michael Oxley, as the main architects of the act. The SOX contains strict regulations concerning preparation procedures of company's financial report which should be appropriately followed by all companies in the United States. It contains some provisions that not included in prior financial report regulations, for example Section 202 that required a periodic statutory financial reports are to include certifications that:

- The signing officers have reviewed the report;

- The report does not contain any material untrue statements or material omission or be considered misleading;

- The financial statements and related information fairly present the financial condition and the results in all material respects;

\footnotetext{
${ }^{10}$ Morton A. Pierce (1981). The Regulation of the Issuance and Trading of Securities in the United States and the European Economic Community: A Comparison. Journal of Comparative Corporate Law and Securities Regulation 3 (1981) 129-150. p. 129.

${ }^{11}$ Ibid.

${ }^{12}$ Asril Sitompul, Zulkarnaen Sitompul and Bismar Nasution (2005). Insider Trading. Kejahatan di Pasar Modal. (Bandung: BookTerrace \& Library) p. 10.

${ }^{13}$ Ibid.
} 
- The signing officers are responsible for internal controls and have evaluated these internal controls within the previous ninety days and have reported on their findings;

- A list of all deficiencies in the internal controls and information on any fraud that involves employees who are involved with internal activities;

- Any significant changes in internal controls or related factors that could have a negative impact on the internal controls.

Organizations may not attempt to avoid these requirements by reincorporating their activities or transferring their activities outside of the United States. In Section 401 stated that Financial statements are published by issuers are required to be accurate and presented in a manner that does not contain incorrect statements or admit to state material information. These financial statements shall also include all material off-balance sheet liabilities, obligations or transactions. The Commission was required to study and report on the extent of off-balance transactions resulting transparent reporting. The Commission is also required to determine whether generally accepted accounting principals or other regulations result in open and meaningful reporting by issuers.

Section 404 of the SOX stipulated that issuers are required to publish information in their annual reports concerning the scope and adequacy of the internal control structure and procedures for financial reporting. This statement shall also assess the effectiveness of such internal controls and procedures. The registered accounting firm shall, in the same report, attest to and report on the assessment on the effectiveness of the internal control structure and procedures for financial reporting.

\section{Disclosure Requirement}

The 1933 Act and 1934 Act require the disclosure of material information at the time that securities are issued and as long as they are traded. This emphasis upon providing investors with accurate information on a continual basis reflects the philosophy of disclosure that underlies the U.S. securities laws. ${ }^{14}$

A public company with securities registered under either Section 12 or which is subject to Section 15(d) of the 1934 Act, have to file reports with the SEC and fulfilled all SEC reporting requirements.

The basis of the requirements is to keep shareholders and the markets informed in a transparent manner. A company also imposed to have record keeping and to implement internal accounting controls subject to the SOX. The SOX required the CEO/CFO certifications requirements, prohibit officer and director loans, and also contain requirements about independent auditor. Under the certification requirement, the CEO and CFO must personally certify the content of the reports filed with the Commission and the procedures established by the issuer to report disclosures and prepare financial statements.

In addition to the disclosure requirement, the SOX also instituted a statutory mandate to improve disclosure in areas such as pro forma financial information, off-balance sheet financial information, and disclosure of the financial expertise of audit committee members. $^{15}$

\footnotetext{
${ }^{14}$ Ibid. p. 130.

${ }^{15}$ Ethiopis Tafara, Acting Director, Office of International Affairs U.S. Securities and Exchange Commission. Addressing International Concerns under the Sarbanes-Oxley Act. Remarks before the American Chamber of Commerce in Luxembourg, June 10, 2003.
} 


\section{Compliance Requirement}

At the time a company entered the stock market, it has to comply with lots of rules and regulations that called securities regulation. Securities regulation comprises the regulation of public issuers of securities, secondary markets, asset management products and market intermediaries ${ }^{16}$ and many others that limiting the 'movement' company in running its business. The market regulations also consist of supervisory regulations and disciplinary regulations imposed by regulatory bodies. In some countries, the supervisory programs were deemed adequate, but disciplinary powers were used very scarcely, which undermines the credibility of the regulator. ${ }^{17}$

Compliance requirement for foreign companies are stated in NYSE Listed Company Manual (the Manual). Section 303A of the Manual stipulated that all companies listed on the Exchange must comply with certain standards regarding corporate governance as codified in this Section 303A, consistent with the NYSE's traditional approach, as well as the requirement of the Sarbanes-Oxley Act of 2002. ${ }^{18}$ Listed companies that are foreign private issuers as defined in Rule 3b-4 under the Exchange Act are permitted to follow home country practice in lieu of the provisions of this Section 303A, however, such companies are required to comply with the requirements of Sections 303A.06, 303A.11 and 303A.12(b) and (c). Section 303A.06 of the Manual stipulated that listed companies must have an audit committee that satisfies the requirements of Rule 10A-3 under the Exchange Act. ${ }^{19}$ Section 303A.11 regulated that Listed foreign private issuers must disclose any significant ways in which their corporate governance practices differ from those followed by domestic companies under NYSE listing standards. ${ }^{20}$

Section 303A.12 (b) and (c) of the Manual are about Certification Requirements:

(a) Each listed company CEO must certify to the NYSE each year that he or she is not aware of any violation by the listed company of NYSE corporate governance listing standards, qualifying the certification to the extent necessary. (b) Each listed company CEO must promptly notify the NYSE in writing after any executive officer of the listed company becomes aware of any non-compliance with any applicable provisions of this Section $303 A .^{21}$

\section{Internationalization of the Act}

There are some ways to bring law of one country to other countries that is transplantation, diffusion and internationalization. On one side, legal transplantation can take place by means of cribbing or retrieval legal system or provisions of a state by other states, and by means of mixing between the provisions of the law of the country with other countries. Legal transplant is already known in the concept of comparative law. According to Watson (1976), the transplantation of law, which is necessary and desirable loan of legal provision and has been practiced in various legal systems, where the law provisions that is derived from one legal system put into other legal system is the essence of the concept of

\footnotetext{
${ }^{16}$ Ana Carvajal and Jennifer Elliott (2007). Strengths and Weaknesses in Securities Market Regulation: A Global Analysis. IMF Working Paper. Monetary and Capital Markets. November 2007. p.6.

17 Ibid

${ }^{18}$ NYSE Listed Company Manual Section 303A.

${ }^{19}$ NYSE Listed Company Manual Section 303A.06.

${ }^{20}$ NYSE Listed Company Manual Section 303A.12 (b) and (c).

${ }^{21}$ NYSE Listed Company Manual Section 303A.11.
} 
comparative law in practical, which offers an improvement to a specific legal system. ${ }^{22}$ While law diffusion according to Twinning (2004) have more broad meaning than legal transplant, he stated: Since 1959 the study of diffusion of law has proceeded under many labels including reception, transplants, spread, expansion, transfer, exports and imports, imposition, circulation, transmigration, transposition, and trans-frontier mobility of law. ${ }^{23}$

On the other side, internationalization means to bring something local to the international level. Internationalization can also happened in the field of law, where law provision of a country that supposed to applicable only in that country and is not applicable in other countries, by the concept of internationalization in the field of law, the law provision is brought from one country to be applied in other countries.

The difference between law diffusion and law transplantation is that in transplantation and diffusion, law provisions brought from one country inserted into the legal system or into the legislation in other countries and become the local laws in that country, while in the concept of internationalization law provisions brought from other countries is not blended to or entered into the provisions of the local law, but it remains foreign legal provisions applied in other countries that received it.

In this case, the example of the internationalization of law is the SOX that should be applicable only in the United States to the companies listing on the United States stock exchanges, but in fact, the SOX has also put in place and must be obeyed by all Indonesian companies that have its stock listed on the United States stock exchanges.

\section{RESULT AND DISCUSSION}

\section{The Impact of the Internationalization of SOX to Indonesian Companies}

Regulation C, Rule 405 and Exchange Act Rule 3b-4 stipulated that: The term foreign private issuer means any foreign issuer other than a foreign government except an issuer meeting the following conditions:

a. More than $50 \%$ of the outstanding voting securities of such issuer are directly or indirectly owned of record by residents of the United States; and

b. Any of the following:

- The majority of the executive officers or directors are United States citizens or residents;

- More than $50 \%$ of the assets of the issuer are located in the United States; or

- The business of the issuer is administered principally in the United States.

In accordance with the rules and regulation stated above, most of Indonesian companies registered with the SEC are treated as foreign private issuer and as foreign private issuer Indonesian companies are required to file financial report in the Form-20F. Financial Reporting Manual issued by Division of Corporation Finance of the SEC, Section 6240.1 stipulated that: An annual report on Form 20-F is required to be filed within four months after the foreign private issuer's fiscal year-end. If the audited financial statements for the most recently completed fiscal year have been included in a registration statement before the four month due date of the annual report on Form 20-F, the due date of the Form 20-F remains at four months. While many companies in this situation file the Form 20-F early,

\footnotetext{
${ }^{22}$ Alan Watson (1976). 'Legal Transplants and Law Reform' 92 Law Quarterly Review 79; Alan Watson (1978) 'Comparative Law and Legal Change' 37 Cambridge Law Journal 313; Alan Watson (1993), Legal Transplants: An Approach to Comparative Law $\left(2^{\text {nd }} . e d\right)$.

${ }^{23}$ William Twining (2004). Diffusion of Law: A Global Perspective. Journal of Legal Pluralism $2004-$ nr. 49. p. 5.
} 
there is no requirement to do so.

Indonesian companies registered with the SEC are required file financial report with reconciliation to U.S. GAAP. The reconciliation to U.S. GAAP must be audited. The SEC recommends that the report of the independent accountant refer explicitly to the reconciliation, but the absence of that reference does not relieve the auditor of its responsibility to examine the reconciliation. In filling the financial report to SEC, effective January 1, 2000, AICPA SEC Practice Section rules established minimum requirements for the review of SEC filings by a designated 'filing reviewer' within the independent accountant's U.S. firm or international organization knowledgeable about U.S. GAAP, U.S. GAAS, U.S. auditor independence and SEC reporting requirements. As foreign private issuers Indonesian companies are required to provide disclosures in the event of a change in their independent accountants. The disclosure requirements are contained in Item $16 \mathrm{~F}$ of Form $20-\mathrm{F}$.

In 2001 and 2002, a spate of major corporate accounting scandals came to light that exposed weaknesses in corporate governance, audit practices, and financial reporting. Congress responded by passing the SOX in 2002, that considered as the most significant piece of securities legislation since the 1930s. ${ }^{24}$

The Act called for increased oversight of auditors of public companies through the creation of the Public Company Accounting Oversight Board. It directed the Commission to establish rules prohibiting auditors from providing certain non-audit services to audit clients and requiring management and auditor reporting on the effectiveness of public companies' internal controls. It increased penalties for violations of securities laws and required certification of financial results by key corporate officers. Through these and other provisions, the Act called for improvement in the system of checks and balances that govern the production of financial information provided to investors. ${ }^{25}$

The Act also mandated that the Commission conduct a study of off-balance sheet transactions and the use of special-purpose entities (SPE). The Act does not discuss why off- balance sheet arrangements and SPEs are identified for special attention, for that purpose we better looking back at the scandals that preceded the passage of the Act. At the beginning of 2001, Enron Corp. enjoyed a market capitalization that exceeded $\$ 60$ billion, ranked as the seventh largest corporation in the world by revenue, and had won Fortune magazine's award as the 'most innovative company in the United States' six years running. Yet, toward the end of 2001, Enron collapsed within a matter of months, filing for bankruptcy protection under Chapter 11. Its collapse constituted the largest corporate bankruptcy up to that point in time. ${ }^{26}$

This event acted as a catalyst - especially after it was rapidly followed by other highprofile business and financial reporting failures, including those at World.Com and Adelphia and raised many questions about corporate governance, the audit process, and financial reporting in general. ${ }^{27}$ The series of financial reporting scandals indicated that the system of corporate governance and financial reporting was in need of repair. In response to these scandals, the Sarbanes-Oxley Act called for improvement in the checks-andbalances that govern the production of financial information provided to investors. ${ }^{28}$

The SOX has been the root of much discussion and debate over the past three years. The

\footnotetext{
${ }^{24}$ The Sarbanes-Oxley Act of 2002, Pub. L. No. 107-204, 2002

${ }^{25}$ See: the Sarbanes-Oxley Act 2002 sections 101-109, section 201, section 404 and sections 901 to 906.

${ }^{26}$ See: Office of the Chief Accountant Office of Economic Analysis Division of Corporation Finance United States Securities and Exchange Commission: Report and Recommendations Pursuant to Section 401(c) of the ${ }^{27}$ Ibid.p. 16 .

${ }^{28}$ Ibid.p.19.
} 
purpose of SOX was to restore public confidence in the markets after this confidence was weakened by these scandals through various requirements which include, among other things financial reporting requirements and corporate governance expectations. It imposes additional burdens on doing business in an effort to make the firm and its executives more accountable for the corporate governance, business operations, and financial reporting of the company. ${ }^{29}$

The negative impact which ever happened due to the application of SOX in Indonesia occurred in one Indonesian company that listed its stock on NYSE. The company has several subsidiaries, and when the company submitted the annual report there is a requirement to consolidate financial report all of subsidiaries into the financial statements of the company as a parent company. A problem occurred at the time because the financial report of the parent company and subsidiaries were not audited by the same independent accountants. So when the financial statements of one of the subsidiaries will be consolidated into the parent company's financial statements, there is a provision that the parent company auditors that will consolidate the results of the audit of the financial statements of the subsidiaries must get a 'consent letter' from the auditor of the subsidiary. What happened was that the auditor of a subsidiary 'unwilling' to give a consent letter, and send letters whose contents were did not clear on whether or not to give permission to the auditor of the parent company. The parent company of Auditors considers that the letter is already a consent letter, and continued to consolidate the financial statements that have been audited by the auditor of the subsidiary. Auditor of the subsidiary filed a report to the SEC on the grounds that the auditor's report quoted financial statement of subsidiary without the consent letter, and that the auditor of parent company is not listed on PCAOB (Public Company Accounting Oversight Board). ${ }^{30}$ Because the SOX requires that accounting firms must register with the PCAOB to prepare or issue an audit report for a public company or another issuer, or a broker-dealer, or to play certain roles in those audits. ${ }^{31}$ The SEC gave reprimand to the parent company by declaring that the parent company must perform a re-audit of its financial report and should hire an accountant registered with $\mathrm{PCAOB}$. It raises the cost for the company having to do the re-audit and re-hiring another auditor that registered with PCAOB.

In addition, the SOX also adopted a new rule to direct the national securities exchanges and national securities associations to prohibit the listing of any security of an issuer that is not in compliance with the mandated audit committee requirements, relating to the independence of audit committee members. The audit committee has responsibility to select and oversee the company's independent accountant, procedures for handling complaints regarding the company's accounting practices, the authority of the audit committee to engage advisors, and funding for the independent auditor and any outside

\footnotetext{
${ }^{29}$ Scott E. Miller (2011). Impact of the Sarbanes Oxley Act on Foreign Companies in the United States: An Analysis. International Journal of Management. Volume: 28. Issue: 1 Publication date: March 2011.

${ }^{30}$ The PCAOB is a nonprofit corporation established by Congress in accordance with Sec. 101 of the Sarbanes-Oxley Act 2002 to oversee the audits of public companies in order to protect investors and the public interest by promoting informative, accurate, and independent audit reports. The PCAOB also oversees the audits of brokers and dealers, including compliance reports filed pursuant to federal securities laws, to promote investor protection. The Sarbanes-Oxley Act of 2002, which created the PCAOB, required that auditors of U.S. public companies be subject to external and independent oversight for the first time in history. Previously, the profession was self-regulated. The five members of the PCAOB Board, including the Chairman, are appointed to staggered five-year terms by the Securities and Exchange Commission, after consultation with the Chair of the Board of Governors of the Federal Reserve System and the Secretary of the Treasury.

${ }^{31}$ Section 101 and 102 of the Sarbanes-Oxley Act of 2002
} 
advisors engaged by the audit committee. ${ }^{32}$

In Indonesia, in relation to the implementation of the good corporate governance, a listed company must have the followings: a. The number of independent commissioners which is in proportion to the total number of shares owned by the non-controlling shareholders provided that the number of independent commissioners shall comprise 19 at least $30 \%$ of the total members of the board of commissioners; b. Audit committee; and c. Corporate secretary.

Requirement to have audit committee is stipulated in the Decision of Head of Stock Market Supervisory Body (BAPEPAM) No. Kep-29/PM/2004, in Article 2, which stated that every issuer or public company is require to establish Audit Committee as stipulated in the attachment of this Decision, no longer than December $31^{\text {st }} 2004$. Then the requirement for listed companies to have audit committee had adopted by Indonesian Financial Services Authority (FSA) by issuing Regulation of Financial Services Authority Number 55/POJK.04/2015 Regarding Development and Working Guidance of Audit Committee (FSA Reg.55/2015). Section 10 of the FSA Reg. 55/2015 stipulated that in carrying out its functions, the Audit Committee has the duty and responsibility to at least include the following:

- Reviewing the financial information to be issued by Issuers or public companies to the public and/or authorities among others financial statements, projections, and other reports related to the financial information of the Issuer or a public company;

- Reviewing over obedience to the laws and regulations related to the activities of Issuers or public companies;

- Provide independent opinion in the event of differences of opinion between management and accountants over the services they provide;

- Provide recommendations to the Board of Commissioners regarding the appointment of accountants based on independence, the scope of the assignment, and fee of services;

- Reviewing the implementation of audit of the internal auditor and overseeing the follow-up by the Board of Directors upon the internal auditor's findings;

- Reviewing the implementation of the risk management activities conducted by the Board of Directors, if Issuers or public companies do not have the risk monitoring functions under the Board of Commissioners;

- Examines complaints related to accounting and financial reporting processes of Issuers or public companies;

- Examines and provides advice to the Board of Commissioners associated with the existence of a potential conflict of interest the issuer or public company; and

- Maintaining the confidentiality of the documents, data, and information of Issuers or public companies.

The requirement to have independent commissioner, which stipulated in Law No.40/2007 and requirement to have an audit committee that stipulated in FSA Reg. $55 / 2015$ are another form of internationalization of the SOX, which is in the form of legal transplant, it is worth to notice that both law and regulation is enacted after the enactment of SOX.

In fact, Indonesian company law adopted two-tier system, which requires all limited liability corporations have two boards, that is the board of director (BOD) and the board of

\footnotetext{
${ }^{32}$ Section 301 of the Sarbanes-Oxley Act of 2002.
} 
commissioner (BOC). With this system, actually the presence of audit committee is not necessary, because the duty to supervise and control of day to day management of the corporation has already burdened to the BOC, as stipulated in Article 1.1 of Law No. 40/2007:

"Board of Commissioner is the organ of corporation that has duty to supervise the corporation in general/particular matter in accordance with the article of incorporation as well as to give advice to Director."

The details of Commissioner's duty are stipulated in Article 114 to 121 of Law No. 40/2007, and if we review it carefully, we can see that some articles adopted the concept of corporate law applicable in the U.S, such as the requirement to establish a committee to assist commissioner to do supervision in Article 121 of the Law.

It is different with the system of corporate law in the U.S that adopted one-tier system, where there is only one board (the BOD) in the company, the company does not have commissioner. In practice, the BOD in one-tier system may have double position, that to be director (President Director) as supervisor of the corporation and to be an officer (the Chief Executive Officer) to run day to day management of the corporation. In this system it is difficult to make a clear division of duties and responsibilities in one person, who have the double position, so it is necessary to have an independent body to be a supervisor, that way it is required to the company to have an audit committee.

Besides the listing of Indonesian companies on the U.S stock exchanges, there also the U.S and foreign financial companies investing in Indonesia, through the Indonesia Stock Exchange. The presence of the U.S and other foreign companies take an important part in investment in the stock market. Many foreign companies acted as the underwriter and/or broker in the stock market. ${ }^{33}$ Regulation regarding requirement to have audit committee and other regulations related to stock market, not only driven by the listing of Indonesian companies on the U.S stock exchanges, but it is also driven by the fact that many of investor or trader in Indonesia stock market are owned or connected to foreign financial companies particularly from the U.S. It cannot be denied that the U.S and other foreign companies bring the strong influence to the market law and regulation in Indonesia. We can see the influence in law and regulations regarding stock market in Indonesia, such as the law and regulations stated previously in this paper.

\section{CONCLUSION}

The internationalization of SOX brings positive and negative impact to Indonesian companies that listing on the U.S securities market. The positive impact to Indonesian companies is, not only the U.S listed companies, but also all public companies listed on Indonesia stock exchange have to be compliance to regulations related to good corporate governance and have to be transparent and fulfill disclosure requirement. The negative impact is it bring more complicated listing requirement in Indonesia stock exchange and may add more cost to public companies in Indonesia.

Part of investment in Indonesian stock market is owned by the U.S and other foreign companies. It made the authorities have to set law and regulations to attract the investor to invest in Indonesian stock market. The law and regulations as the impact of internationalization of foreign law, sometime not be able to apply to Indonesian companies because some regulation is overlapping with other law and regulations that have already exist in Indonesia. 


\section{REFERENCES}

Albornoz, Belén Gill de and Pope, Peter F. (2004). The Determinants of the Going Public Decision: Evidence From the U.K. Editor: Instituto Valenciano de Investigaciones Económicas, S.A. Primera Edición Junio 2004.

Andrieş, Alin Marius (2009). The Importance of Capital Market in Economy. CES Working Papers, I, (2), 2009.

Asril Sitompul, Zulkarnaen Sitompul and Bismar Nasution (2005). Insider Trading.

Kejahatan di Pasar Modal. (Bandung: BookTerrace \& Library).

Carvajal, Ana and Elliott, Jennifer (2007). Strengths and Weaknesses in Securities Market Regulation: A Global Analysis. IMF Working Paper. Monetary and Capital Markets. November 2007.

Clarke, Jonathan, Jandik, Tomas, Mandelker, Gershon (2018). The Efficient Markets Hypothesis. http://www.e-m-h.org. accessed 10 February 2018.

Ethiopis Tafara, Acting Director, Office of International Affairs U.S. Securities and Exchange Commission. Addressing International Concerns under the Sarbanes-Oxley Act. Remarks before the American Chamber of Commerce in Luxembourg, June 10, 2003.

EY (2013). EY's guide to going public. Lessons from the leaders. EYGM Limited. 